\title{
INTERLINGUAL ERRORS AND INTRALINGUAL ERRORS FOUND IN NARRATIVE TEXT WRITTEN BY EFL STUDENTS IN LAMPUNG
}

\author{
Eny Maulita Purnama Sari \\ SMK Negeri I Pekalongan. \\ Desa Sidodadi, Kecamatan Pekalongan Lampung Timur, Lampung \\ m.enny42@yahoo.com
}

\begin{abstract}
The current study investigates the interference of L1 (Indonesian) into L2 (English) and the errors that occur due to the influence of TL (target language). The focus of the study is on the errors committed by these EFL students in writing narrative text and emphasized on interlingual errors and intralingual errors. The objectives of the study are to investigate the errors committed by these EFL students in order to find out; (1) the types of interlingual errors and intralingual errors in Junior High School, Senior High School and University, (2) the frequencies of interlingual errors and intralingual errors in Junior High School, Senior High School and University, and (3) the similarities and differences of interlingual errors and intralingual errors in Junior High School, Senior High School and University. The researcher used Qualitative descriptive as the method design and writing test as the data collecting technique. The data was erroneous sentences found in the students' narrative writing. The subjects of the study comprised 30 eight grade of SMP Muhammadiyah Pekalongan, East Lampung and 30 eleven grade SMKN 1 Pekalongan, East Lampung, and 30 fourth-year students of English Department of University of Muhammadiyah, Metro Lampung. The findings of the study suggest: (1) The types of interlingual errors and intralingual errors made by SMP, SMK and University students divided into 2 levels, they are morphological level and syntactical level. (2) the frequent of interlingual errors in Junior High School 36 cases (30.26\%), in Vocation High School 39 cases $(36.77 \%)$ and 9 cases (10.98\%) in University. The frequent of intralingual errors in Junior High School 83 cases (69.74\%), in Senior High School 70 cases (64.23\%) and 73 cases (89.02\%) in University, and (3) The similarities of interlingual errors and intralingual errors found in Junior High School, Vocation High School and University are 2 types. In morphological level, they are the use of L1 structures and omission of $B E$ in nominal sentences. There are also 2 types in syntactical level, they are the use of present BE in past event and the use of present Verb in past event. The differences of interlingual errors and intralingual errors found in SMP, SMK and University are (1) in SMP there are 8 types errors that found in the students'writing, (2) 3 types of errors in SMK, and (3) 2 types of errors found in University.
\end{abstract}

Keywords: error analysis, interlingual error, intralingual error, narrative text

\begin{abstract}
ABSTRAK
Penelitian ini berkenaan dengan kesalahan berbahasa Inggris yang disebabkan oleh pengaruh bahasa ibu (Bahasa Indonesia) dipengaruhi oleh bahasa target. Fokus dari penelitian ini pada kesalahan yang dilakukan oleh siswa (EFL) dalam menulis teks naratif dan menekankan kesalahan interlingual dan kesalahan intralingual. Tujuan penelitian ini adalah (1) mengidentifikasi jenis kesalahan interlingual dan kesalahan
\end{abstract}


intralingual yang ditemukan pada tulisan siswa SMP, SMK, dan Perguruan Tinggi, (2) menggambarkan frekuensi kesalahan interlingual dan kesalahan intralingual di SMP, SMK dan Perguruan Tinggi, serta (3) mendeskripsikan kesamaan dan perbedaan dari kesalahan interlingual dan kesalahan intralingual di SMP, SMA, dan Perguruan Tinggi. Penulis menggunakan tes menulis teks naratif untuk mendapatkan data dari siswa. Subjek penelitian terdiri dari 30 siswa kelas delapan SMP Muhammadiyah Pekalongan, Lampung Timur, 30 siswa kelas sebelas jurusan Akutansi SMKN 1 Pekalongan, Lampung Timur, dan 30 mahasiswa semester 4 Jurusan Bahasa Inggris Universitas Muhammadiyah Metro Lampung. Hasil penelitian meliputi hal-hal berikut. (1) Jenis kesalahan interlingual dan kesalahan intralingual yang dibuat oleh siswa SMP, siswa SMK, dan mahasiswa dibagi menjadi 2 tingkatan kesalahan, yaitu morfologi dan sintaksis. (2) Kesalahan interlingual di SMP ditemukan 36 kasus (30,26\%), Pada SMK 39 kasus (36,77\%), dan 9 kasus (10,98\%) di Perguruan Tinggi. Selanjutnya, kesalahan intralingual yang ditemukan pada SMP, yakni 83 kasus $(69,74 \%), 70$ kasus $(64,23 \%)$ pada SMK dan 73 kasus $(89,02 \%)$ pada Perguruan Tinggi. (3) Kesamaan kesalahan interlingual dan kesalahan intralingual ditemukan di SMP, SMK, dan Perguruan Tinggi mencakup 2 tipe kesamaan pada tingkat morfologi. Kesalahan-kesalahan tersebut adalah penggunaan struktur bahasa ibu (L1) dan kelalaian penggunaan BE pada kalimat nominal di bahasa Inggris. Ada 2 tipe kesalahan pada level sintaksis. Kesalahan-kesalahan tersebut adalah penggunaan present BE pada kalimat lampau dan menggunakan present verb dalam kalimat lampau. Perbedaan kesalahan interlingual yang ditemukan di SMP, SMK, dan Perguruan Tinggi mencakup 8 tipe kesalahan intralingual pada hasil tulisan siswa SMP, 3 tipe kesalahan pada hasil tulisan siswa SMK, dan 2 tipe kesalahan yang dibuat oleh mahasiswa Perguruan Tinggi.

Kata Kunci: analisis kesalahan berbahasa, kesalahan bahasa antar, kesalahan intrabahasa, teks naratif

\section{INTRODUCTION}

In foreign language learning, the students are supposed to master the language skills, either communicative competence in spoken or written competence in English texts. One of the objectives of English teaching to the English learner is to develop their communicative competence. Writing is one skill that must be mastered by the students. When mastering it, the students will be able to communicate with other through several kinds of genre-based writing such as descriptive, recount, narrative, procedure and report. Mastering it will help them to produce articles and compositins, to do exams, to make letters, etc.

As it is generally accepted that writing in English is a complex process for English as a foreign language learners (EFL), it is not surprising that errors in writing are found as an unavoidable part of EFL student writing. Ellis (1997) notes fossilization of learners' grammar does not occur in first language (L1) acquisition, but is unique in second language (L2) acquisition.

There are many aspects that cause the learners of English as a foreign language make errors. Brown (1980: 160) said that the learners' errors in the second language result from the learner's assumption that the second language forms are similar to the native language 
(interlingual errors) and the negative transfer of items within the target language (intralingual errors).

This condition happens in SMP, SMK and University students. They ever make an error in their writing such as interlingual errors and intralingual errors. They take the bahasa Indonesia's structure to the English. For the example: (1) Interlingual errors, "I am hearing you" word honorific jackai. (2) Intralingual errors, In the wood there is mouse deer very be lazy.

The phenomenon above described that there were any errors created by the students. From the examples of interlingual errors, the students wrote a false word order in their sentences. From the intralingual one, sentence was written in present form although it was used for indicating past event.

Based on the phenomenon in the field, the researcher would like to find the interlingual and intralingual interference in the students' text so the researcher want to take a research about narrative text focused on the interlingual errors and intralingual errors found in writing narrative texts by EFL Students in different level of school to know whether there are any significant differences of the error made by students in different level in Lampung. In this case, researcher is interested in conducting a study entitled "Interlingual errors and Intralingual Errors Found in Narrative Text Written by EFL Students in Lampung."

The aim of this paper is to identify and describe students' errors interlingually and intralingually. It is also intended to draw teacher's attention on the situation of our students because it is necessary to determine the areas that require remedy in order to think of appropriate solutions.

\section{The Concept of Error}

The first step in Error Analysis (EA) requires the determination of elements in the sample of learner language which deviate from the TL in some way. For this purpose, distinction should be made between error and mistake. According to James (1998:77) an error arises "only when there was no intention to commit one". Errors are systematic, consistent deviance which is characteristic of the learning produced by learner' linguistics system at given stage of learning. Errors are typically produced by learners who do not yet fully command some institutionalized language system; they arise due to the imperfect competence in the target language.

Whereas, according to Fauziati (2009: 139) the mistakes are deviations due to performance factors such as memory limitation, fatigue and emotional strain. They are typically irregular and can be readily corrected by the learners themselves when their attention is drawn to them.

\section{a. Interlingual Error}

Interference, language transfer, and cross-linguistic interference are also known as interlingual errors. Corder (1981) states that these kinds of error occur when the learner's habits (patterns, systems or rules) interfere or prevent him or her, to some extent, from acquiring the patterns and rules of the second language. Lado (1964) said Interference (negative transfer) is negative influence of the mother tongue (L1) on the performance of the target language (L2). Chelli (2013) defined that interlingual errors are the result of language transfer, which is caused by learner's first language.

Richard (1974:173) states if the learners of a foreign language make mistake in the target language by effect of his mother tongue that is called as interlingual. As stated by Brown (1980: 160), most of the learners' errors in the second language result primarily from the learner's assumption that the second language forms are similar to the native language. 
According to Allen and Corder (1974), Interlingual errors are caused by transfer error. Touchie (1986) suggested that interlingual errors are caused mainly by mother tongue interference. Another researcher is Al-Khresheh (2010). He suggested that interlingual errors is committed by literal translation.

1) Transfer Error: error caused by interference from mother tongue. A student who has not known the rules of target language will use the same rules as he obtained in his native language.

2) Mother tongue Interference: errors are produced in the learners' attempt to discover the structure of the target language rather than transferring models of their first language.

3) Literal Translation: errors happen because a student translates his first language sentence or idiomatic expression in to the target language word by word.

\section{b. Intralingual Error}

Interference from the student's own language is not the only reason for committing errors. Students may make mistake in the target language, since they do not know the target language very well, they have difficulties in using it. Richard (1974: 6) states, intralingual interference refers to items produced by learner, which reflect not the structure of mother tongue, but generalization based on partial exposure of the target language.

Brown (1980: 162) said that it has been found that the early stages of language learning are characterized by a predominance of interlingual transfer, but once that learner has begun to acquire parts of the new system, more and more transfer generalization within the target language is manifested.

Richard (1974: 120) classifies the intralingual errors into four categories including over generalization, ignorance of rule restrictions, incomplete application of the rules, and false concept hypothesized or semantic errors.

1) Overgeneralization: it happens when a learner creates a deviant structure on the basis of his experience of other structure in the target language. Littlewood (1984) cites the example of forming plural by adding "s" to even irregular plurals, also generalizing the "-ed" past form.

2) Ignorance of Rule Restrictions: James (1998: 63) that ignorance is specific in the sense that one is normally said to be ignorant of structure; the learner of the second language does not obey the structure of the target language. In this type of error, the learner fails to observe the restrictions of existing structures. Some rule restriction errors may be accounted for in terms of analogy and may result from the role learning of rules.

3) Incomplete Application of the Rules: this error may occur when learner fails to apply the rules completely due to the stimulus sentence.

4) False Concept Hypothesized: learners' faulty understanding of distinctions of target language items leads to false conceptualization. Learners' faulty understanding of distinctions of target language items leads to false concept hypothesized.

\section{LITERATURE REVIEW}

In the 1950s the behaviorists learning theory described language as habit formation and explained why second or foreign language learners made errors. According to that theory, old habits hinder or facilitate new habits. There was the danger of errors becoming habits if they 
were tolerated, so they should be avoided. According to the cognitive approach, the making of errors is inevitable and a necessary part of learning. Chomsky (1998) confirmed that errors are unavoidable and a necessary part of learning. They are visible proof that learning is taking place. Thus, Corder (2000) proposed that not only language learners necessarily produce errors when communicating in a foreign language, but these errors, if studied systematically can provide insight into how languages are learnt. He also agrees that studying students' errors of usage has immediate practical application for language teachers. Candling (2001) considered EA as the monitoring and analysis of learners language. Error analysis can be used to determine what a learner still needs to be taught. It provides necessary information about what is lacking in his or her competence. Weinreich (1991) also considered learners' errors to be of particular importance because making errors is a device the learners use in order to learn. According to him EA is a valuable aid to identify and explain difficulties faced by learners. He goes on to say that EA serves as a reliable feedback to the design of a remedial teaching method. Conducting error analysis is therefore one of the best ways to describe and explain errors committed by L2 learners. This kind of analysis can reveal the sources of these errors and the causes of their frequent occurrence. Once the sources and causes are revealed, it is possible to determine the remedy, as well as the emphasis and sequence of future instructions.

Indonesia is a country where English is taught as a foreign language. As a result, learners commit serious errors due to the interference (interlingual transfer) from their L1 and the negative transfer of items within the target language (intralingual errors).

Researchers such as George (1972), Lance (1969), Richards (1971), and Brudhiprabha (1972) also found that only one-third of the second language learners' errors can be attributed to native language transfer. Other studies by Falhasiri (2011), indicated that the most errors were interlingual category (71\%). It was also concluded that in 22 out of 26 categories, the frequency of errors decreased. Deductive (explicit) teaching of interlingual and also inductive (implicit) teaching of intralingual erroneous points decreased the error frequency of students. Moreover, interlingual errors were more affected than intralingual in case of error reduction.

Al-Khresheh $(2010,2011)$ states that interlingual errors commited by the result of wordfor-word (literal translation) from Arabic. It meant that interlingual interference might be the main cause of committing this huge number of these errors.

In a study, Kafipour and Khojasteh (2012) found (1) seven categories of errors that found in the data which could be categorized under interlangual errors. It is $16.19 \%$ of overall errors can be refered to as interlingual errors. (2) There were five different errors found as ambiguous errors made by the learner which $20 \%$ of overall errors made by learners can be reffered to as ambiguous errors. (3) There are eight different types of errors could be categorized under developmental errors. It is $40 \%$ of the errors made by learner belong to developmental errors

In another study, Chelli (2013) found that the students' errors in the using 'of' preposition and article can be identified into interlingual and intralingual errors. The result showed that $79.15 \%$ of the errors made in preposition and $72.85 \%$ in articles are caused by negative transfer of the Arabic language. $20,85 \%$ in the use of prepositions and $27,15 \%$ in the use of articles due to overgeneralization and false concepts hypothesized mainly because of lack of practice.

In study conducted by Solano (2014), he found that the most common Spanish interference errors were misuse of verbs, omission of personal and object pronouns, misuse of preposition, overuse of articles and inappropriate/unnatural word order. It shows that L1 caused interference in EFL learners when writing in English, which often due to the fact that there is a linguistic transference from the native language to the target language.

In conclusion, this study differs from previous studies as it aims to describe interlingual errors and intralingual errors and its implementation. Therefore, it may offer plausible 
explanations of the occurrence of interlingual errors and intralingual errors based essentially on Contrastive Analysis (CA). Unlike other studies which have been conducted earlier that focused on the effects of intralingual interference, performance errors, and overgeneralization errors in the acquisition of English, the present study focuses mainly on interlingual and intralingual errors. Furthermore, this study could be considered novel for two main reasons. First, the findings of this study can be implications for teaching methodology. The second one, the findings also may lead to recommendations that will improve the level of EFL teachinglearning process in beginner, intermediate and advance students in Lampung.

\section{METHOD AND PROCEDURE}

A quantitative descriptive method was used to investigate the types of errors, the frequency of errors, the similarities and differences of interlingual errors and intralingual errors in writing narrative text made by SMP, SMK and University students.

\section{Participants}

The participants of the current study were 30 students of the eighth grade of SMP Muhammadiyah Pekalongan East Lampung, 30 students of SMKN 1 Pekalongan East Lampung and 30 students of fourth-years of English Department of University of Muhammadiyah Metro Lampung. The data sources were 90 students' English composition written productions by the eighth grade of SMP Muhammadiyah Pekalongan East Lampung, SMKN 1 Pekalongan East Lampung and the fourth-years of English Department of University of Muhammadiyah Metro in Academic year 2014/2015.

\section{Data and Data Collection Technique}

The data of this research were the students' erroneous sentences in narrative writing. The sentences were taken from 90 pieces of SMP, SMK, and University students' narrative writing. The researcher used documentation of the students' written production in the form of narrative text. The researcher chooses elicitation technique as the method of data collection, because the data were taken directly from the students.

\section{Data Analysis Technique}

The data were analyzed by using the error analysis suggested by Brown (1980). And to analyze them, the researcher used the following steps: (1) The students' works were identified to interlingual errors and intralingual errors. (2) The students' works were classified into the level of interlingual and intralingual errors. The levels are Phonological level, Morphological level, Syntactical level and Lexical level. (3) The error that was classified will be analyzed based on comparative taxonomy, and the frequency of the errors will be calculated. (4) The finding of the errors will be identified based on the causes of interlangual error and intralingual errors.

\section{FINDINGS AND DISCUSSION}

The data of interlingual errors and intralingual errors are presented in two head categories, morphological level and syntactical level. The Interlingual errors made by Junior High School are divided into 4 subcategories, they are (1) wrong word spelling, consist of 5 cases $(4.20 \%)$, (2) the use of Indonesian word consist of $5(4.20 \%)$, (3) the use of L1 structure consist of 21 cases $(17.65 \%)$ and (4) omission of BE in nominal past sentence consist of 5 cases $(4.20 \%)$. Interlingual errors found in Vocation High School are divided into 4 subcategories, they are 
(1) wrong word spelling consist of 6 cases $(5.51 \%)$, (2) the use of Indonesian word consist of $9(8.26 \%)$, (3) the use of L1 structure consist of 15 cases $(13.76 \%)$ and (4) omission of BE in nominal past sentence consist of 9 cases $(8.26 \%)$ and 2 subcategories in university, they are (1) the use of L1 structure consist of 5 cases (6.10\%), and (2) omission of BE in Nominal Sentence consist of 4 cases $(4.87 \%)$.

The types of intralingual errors made by Junior High school are: (1) omission of suffix (-ed) in regular verb past consist of 8 cases $(6.78 \%)$, (2) the use of present BE in past event consist of 12 cases (14.28\%), (3) Addition of BE in past verbal sentence consist of 15 cases $(12.60 \%),(4)$ the use of present verb in past event consist of 16 cases $(13.44 \%),(5)$ wrong selection of personal pronoun consist of 5 cases $(4.21 \%)$, (6) the use of present auxiliary verb in past event consist of 6 cases $(5.05 \%)$, (7) omission of ('s) as possessive marker consist of 7 cases $(5.88 \%)$ and (8) additional of $\mathrm{S}$ in irregular plural noun consist of 9 cases $(7.56 \%)$. The types of intralingual errors found in Vocation High School are: (1) wrong word spelling consist of 5 cases $(4.59 \%),(2)$ the use of present BE in past event consist of 24 cases $(22.02 \%),(3)$ the use of present verb in past event consist of 34 cases $(31.19 \%)$, (4) omission of s/es in regular plural noun consist of 7 cases $(6.42 \%)$. The types of intralingual errors found in University are: (1) omission of suffix (-ed) in regular verb past consist of 12 cases $(14.63 \%)$, (2) the use of present BE in past event consist of 20 cases $(24.40 \%)$, (3) the use of present verb in past event consist of 36 cases (39.14\%), and (4) wrong selection of pronoun consist of 5 cases $(6.10 \%)$.

Table 1: The frequencycy of Interlingual and Intralingual Errors Made by Junior High School,Vocation High School, and University Students

\begin{tabular}{lcccccc}
\hline \multirow{2}{*}{$\begin{array}{c}\text { Types of } \\
\text { Errors }\end{array}$} & \multicolumn{2}{c}{ Junior High School } & \multicolumn{2}{c}{ Vocation High School } & \multicolumn{2}{c}{ University } \\
\cline { 2 - 6 } & Cases & Percentage & Cases & Percentage & Cases & Percentage \\
\hline Interlingual & 36 & $30.26 \%$ & 39 & $35.78 \%$ & 9 & $9.79 \%$ \\
Intralingual & 83 & $69.74 \%$ & 70 & $64.22 \%$ & 73 & $90.21 \%$ \\
Total & 119 & $100 \%$ & 109 & $100 \%$ & 82 & $100 \%$ \\
\hline
\end{tabular}

The table of frequency of interlingual errors and intralingual errors shows that the most frequent errors are on intralingual. It is due to overgeneralization, false concept hypothesis and incomplete application of language rules.

From the table of comparison of interlingual errors and intralingual errors below, the similarities of interlingual errors and intralingual errors made by SMP, SMK and University students can be identified. The researcher found the similarities of interlingual errors and intralingual errors in students' composition. The similarities of interlingual errors and intralingual errors made by SMP, SMK and University students will be discussed here. The similarities of interlingual and intralingual errors found by researcher are: the use of L1 structures, Omission of BE in nominal sentence, the use Present BE in past event, and the use of Present Verb in past event.

The researcher found, the differences of interlingual errors and intralingual errors made by SMP, SMK and University students are as follows: Wrong Word Spelling and The use of Indonesian word were found in SMP and SMK but were not found in University, omission of BE (was/were) in nominal sentences and Wrong selection of Pronoun, is found in SMP and University and did not find in SMK. the use of BE (is) in past tense, Addition of BE in past verbal sentence, The use of Present Auxiliary Verb in past event, Omission of bound morpheme ('s) as Possessive Marker, Additional of S in Irregular Plural noun were found in SMP, it did not find in SMK and University. And Omission of s/es in Regular plural noun found in SMK, but it did not find in SMP and University. 
Table 2: The Comparison of Interlingual Errors and Intralingual Errors Made by SMP, SMK and University Students

\begin{tabular}{|c|c|c|c|c|c|c|c|}
\hline \multirow{2}{*}{ No } & \multirow{2}{*}{$\begin{array}{c}\text { Types of Interlingual Errors and } \\
\text { Intralingual Errors }\end{array}$} & \multicolumn{2}{|c|}{ SMP } & \multicolumn{2}{|c|}{ SMK } & \multicolumn{2}{|c|}{ University } \\
\hline & & f & $\%$ & f & $\%$ & f & $\%$ \\
\hline & INTERLINGUAL ERRORS & & & & & & \\
\hline 1 & Wrong word spelling & 5 & $4.20 \%$ & 6 & $5.51 \%$ & - & - \\
\hline 2 & The Use of Indonesian Word & 5 & $4.20 \%$ & 9 & $8.25 \%$ & - & \\
\hline 3 & The Use of L1 structure & 21 & $17.65 \%$ & 15 & $13.76 \%$ & 5 & $6.10 \%$ \\
\hline \multirow[t]{2}{*}{4} & $\begin{array}{l}\text { Omission of BE (was/were) in } \\
\text { nominal sentences }\end{array}$ & 5 & $4.20 \%$ & 9 & $8.26 \%$ & 4 & $4.87 \%$ \\
\hline & INTRALINGUAL ERRORS & & & & & & \\
\hline 5 & Wrong word spelling & - & - & 5 & $4.59 \%$ & - & - \\
\hline 6 & $\begin{array}{l}\text { Omission of suffix (-ed) in Regular } \\
\text { Past Verb }\end{array}$ & 8 & $6.78 \%$ & - & - & 12 & $14.63 \%$ \\
\hline 7 & The use of Present BE in past event & 12 & $14.28 \%$ & 24 & $22.02 \%$ & 20 & $24.40 \%$ \\
\hline 8 & $\begin{array}{l}\text { Addition of BE in Past Verbal } \\
\text { Sentence }\end{array}$ & 15 & $12.60 \%$ & - & - & - & - \\
\hline 9 & The use of Present Verb in Past Event & 16 & $13.44 \%$ & 34 & $31.19 \%$ & 36 & $39.14 \%$ \\
\hline 10 & Wrong Selection of Pronoun & 5 & $4.21 \%$ & - & - & 5 & $6.10 \%$ \\
\hline 11 & $\begin{array}{l}\text { The Use of Present Auxiliary Verb in } \\
\text { Past Event }\end{array}$ & 6 & $5.05 \%$ & - & - & - & - \\
\hline 12 & $\begin{array}{l}\text { Omission of bound morpheme ('s) as } \\
\text { Possessive Marker }\end{array}$ & 7 & $5.88 \%$ & - & - & - & - \\
\hline 13 & $\begin{array}{l}\text { Additional of S in Irregular Plural } \\
\text { noun }\end{array}$ & 9 & $7.56 \%$ & - & - & - & - \\
\hline \multirow[t]{2}{*}{14} & $\begin{array}{l}\text { Omission of s/es in Regular plural } \\
\text { Noun }\end{array}$ & - & - & 7 & $6.42 \%$ & - & - \\
\hline & TOTAL & 119 & $100 \%$ & 109 & $100 \%$ & 82 & $100 \%$ \\
\hline
\end{tabular}

Note:

f : Number of cases

$\% \quad$ : Percentage of cases

\section{CONCLUSION}

This study confirmed that the errors made by the learners in Junior High School, Vocation High School and University students are all intralingual errors. The students' errors in interlingual were influenced by the use of L1 structure in making sentence in English (literal translation).The students' errors in intralingual were due to overgeneralization, false concept hypothesis and incomplete application of rule. There might be other causes, but they do not focus on studying English. So, being aware of the causes of learners' idiosyncrasies might indicate pedagogical practice and determine the approach to be adopted. On these cases, the researcher suggests that: The teacher can solve the problem by giving the explicit and implicit corrective feedback and remedial teaching programmed to the students. 


\section{REFFERENCES}

Al- Khresheh, M.H. 2010. Interlingual Interference in English Language Word Order structure of Jordanian EFL Learners. Proceedings of the European Journal of Social SciencesVolume 16, Number 1.

Brown, H, Douglass. 1980. Principles of Language Learning and Teaching, New Jersey: Prentice Hall Inc.

Brudhiprabha, P. 1972. Error analysis: a psycholinguistic study of Thai English compositions. Thesis (M.A.): McGill University

Chelli, Saliha. 2013. Interlingual and Intralingual Errors in the Use of Preposition and Articles. As retrieved from http://dspace.univ-biskra.dz:8080/jspui/bitstream/123456789/3571/1/ Interlingual $\% 20$ or $\% 20$ Intralingal $\% 20$ Errors $\% 20 \mathrm{in} \% 20$ the $\% 20$ Use $\% 20$ of $\% 20$ Preposition.pdf

Chomsky, Noam.1998. Minimalist inquiries: the framework. MIT OPL 15. Dept.of linguistics, MIT.

Corder, S.P. 1981. Error and an Interlanguage. London: Oxford University.

Corder, S.P. 2000. Error Analysis. London: Longman Publisher.

Corder. S,P. 1974. Error Analysis: Perspective on second language acquisition. London. Longman.

Ellis, Rod. 1997. SLA Research and Language Teaching. Oxford: Oxford University Press.

Falhasiri, Mohammad. 2011. "The Effectiveness of Explicit and Implicit Corrective Feedback on Interlingual and Intralingual Errors: A case of Error Analysis of Students' Compositions". Proceedings of the English Language Teaching. Volume 4, Number 3.

Fauziati, Endang. 2009. Readings on Applied Linguistics: A Handbook for Language Teacher and Teacher Researcher. Surakarta: Era PustakaUtama

George, H.V. 1972. Common errors in language learning. Rowley: Massachusetts.

James, C. 1998. Errors in language learning and use: Exploring error analysis. New York: Longman.

Lado, R. 1964. Language Teaching: A Scientific Approach in Students' Text. McGraw-Hill: USA.

Richard, J, C. 1974. Error Analysis: Perspective on Second Language Acquisition. London: Longman Group Ltd.

Solano, Paola Alexandra Cabrera. 2014. Spanish Interference in EFL Writing skills: A case of Ecuadorian Senior High Schools. Canadian Center of Science and Education. Vol. 7 No. 7.

Touchie, Hanna. 1986. Second Language Learning Errors Their Types, Causes, and Treatment. Proceedings of the JALT Journal-Volume 8, Number 1

Weireech, S. 1991. How to Analyze Interlanguage. Journal of Psychology and Education. 9:113-22. 